\title{
Basal cell carcinoma: An unusual localization
}

\section{Kaoutar Laamari, Zakia Douhi, Sara Elloudi, Hanane Baybay, Fatima Zahra Mernissi}

\author{
Departement of Dermatology, University Hospital Hassan II, Fes, Morocco
}

Corresponding author: Dr. Kaoutar Laamari, E-mail: Kaoutar.laamari1@gmail.com

Basal cell carcinoma (BCC) is the most common skin tumor, which accounts for more than $75 \%$ of the nonmelanotic skin cancers and occurs in the head and neck region in $85 \%$ of the cases. The BCC tumor is known to be readily excised and the skin lesion easily closed [1].

BCCs have low mortality but can cause significant morbidity primarily through local destruction.

UV radiation exposure is the most important environmental risk factor. Nodular BCC appears mostly in head and neck regions, while its occurrence in legs is extremely rare [2].

Differential diagnoses for this case were squamous cell carcinoma, and malignant melanoma. The nodular subtype found here is reported to be the most common on extra-facial locations.

Surgery and radiotherapy appear to be the most effective treatment modalities, with surgery showing the lowest failure rates [3].

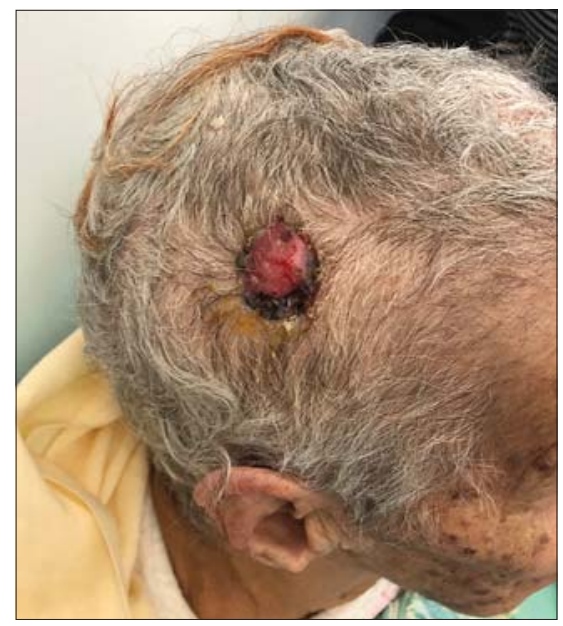

Figure 1: A $2 \mathrm{~cm}$ pigmented oval plaque on the scalp.
A 65-years-old women presents a reddish plaque on the scalp evolving more than 3 years. Recently it becomes slightly itchy. Clinically: A $2 \mathrm{~cm}$ pigmented oval plaque on the scalp (Fig. 1). On dermoscopy screening bluegray nests, gray-blue globules, pink white area (Fig. 2). We realized a biopsy. The histopathology concluded to a nodular basal cell carcinoma. We removed the lesion with $5 \mathrm{~mm}$ of margin.

The patient was advised to apply photo protection measures and a follow-up once a year.

\section{Consent}

The examination of the patient was conducted according to the Declaration of Helsinki principles.

The authors certify that they have obtained all appropriate patient consent forms. In the form the patient(s) has/have given his/her/ their consent for his/her/their images and other clinical information to be reported in the journal. The patients understand that their names and initials will not be published and due efforts will be made to conceal their identity, but anonymity cannot be guaranteed.

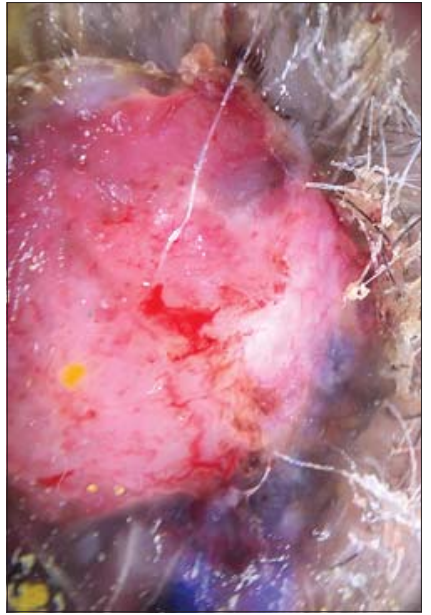

Figure 2: Dermoscopy screening blue-gray nests, gray-blue globules, pink white area.

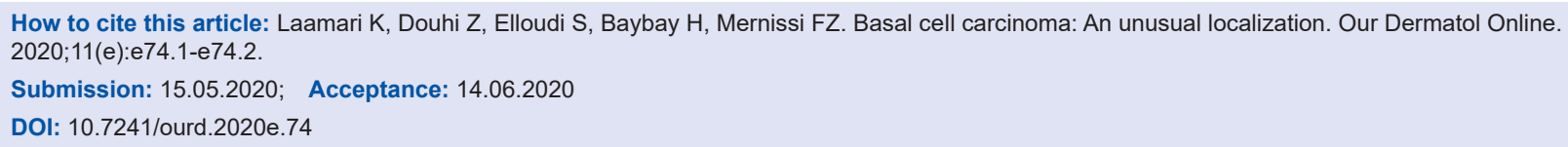


www.odermatol.com

\section{REFERENCES}

1. Lai V, Cranwell W, Sinclair R. Epidemiology of skin cancer in the mature patient. Clin Dermatol. 2018;36:167-76.

2. Bartoš $\mathrm{V}$, Bulejčíková T. Basal cell carcinoma of the skin with clear cell differentation: A report of two cases. Our Dermatol Online. 2016;7:422-6.

3. AL-Bdour NF, El-Maaytah KAM, Arabiyat LA-R, AL Shishi MF, Sayegh OM, Ammar HM. Helical root chondrocutanuous composite graft for nasal reconstruction: Two case reports. Our Dermatol Online. 2019;10:262-4.

Copyright by Kaoutar Laamari, et al. This is an open access article distributed under the terms of the Creative Commons Attribution License, which permits unrestricted use, distribution, and reproduction in any medium, provided the original author and source are credited. Source of Support: Nil, Conflict of Interest: None declared. 